\title{
Quality-adjusted labour input: new quarterly estimates for 1993 to 2009 and annual estimates from 1970
}

Jean Acheson and Mark Franklin

Office for National Statistics

\section{Summary}

Quality-adjusted labour input (QALI) is a measure of labour input to economic production which takes account of the composition of the workforce as well as volume of hours worked. It provides a more complete picture of the input of labour to the production process than traditional measures, which focus only on the quantity of labour input, and therefore provides a broader perspective in assessing productivity performance. Along with the volume index of capital services, QALI is a key input to multi-factor productivity and growth accounting analyses. This article presents new estimates of QALI for 1993 to 2009. The series has been extended by an additional year since the previous release (Turvey, Goodridge and Franklin 2010). An additional section backcasts QALI to 1970 using annual 'labour services' estimates from the EU KLEMS dataset'.

\section{Introduction}

Standard labour productivity measures express growth in output with respect to the volume of labour input, either in terms of employment, jobs or hours worked ${ }^{2}$. The implicit assumption underlying this approach is that labour is homogeneous, as it does not take into account the composition, or quality, of the workforce.

'As a result an hour worked by a highly experienced surgeon and an hour worked by a newly hired teenager at a fast food restaurant are treated as equal amounts of labour'. OECD (2001)

However, labour is far from homogeneous, and the 'value' of an hour worked, or marginal productivity, varies significantly between workers. The quality-adjusted labour input (QALI) series attempts to address this, providing a measure which explicitly recognises the heterogeneity of labour by adjusting the volume of hours worked according to certain characteristics - qualifications, age, gender and industry - which may be indicative of a worker's quality. 
QALI is therefore a conceptually stronger method for use in productivity and growth accounting analyses, and is a useful tool for assessing the evolution of human capital over time. It is used alongside experimental estimates of capital services (such as Appleton 2011) to produce multifactor productivity (MFP) estimates.

This article presents new estimates of QALI for 1993 to 2009. Data are presented for the whole economy, the market sector and for ten industries. QALI is also analysed by education, age and gender. A separate piece of analysis backcasts the QALI time series to 1970 using the EU KLEMS dataset, which produces quality adjusted labour series called 'labour services' that are conceptually similar to QALI.

\section{Methodology}

To perform the quality adjustment, hours worked are differentiated into $n$ types of worker $\left(h_{1}\right.$ to $\left.h_{n}\right)$ determined by their characteristics: age, educational attainment, industry and gender. The reasons for using these particular characteristics are explained in Box 1. The hours worked by these different worker types contribute to total labour input $L$ through a function $g$.

$L=g\left(h_{1}, h_{2}, \ldots, h_{n}\right)$

Economic theory states that in competitive markets with constant returns to scale, labour will be hired until its marginal cost (wage rate) equals its marginal revenue product, or marginal productivity. Therefore, when measuring labour input, using income data as a weight takes into account the relative productivity (or 'quality') of workers as well as the quantity of hours worked.

Following the OECD (2001) recommended methodology, the growth in quality-adjusted hours is represented as a Törnqvist index:

$\Delta \ln L_{t}=\ln \left(\frac{L_{t}}{L_{t-1}}\right)=\sum_{i}\left[\left(\frac{w_{i, t}+w_{i, t-1}}{2}\right) \ln \left(\frac{h_{i, t}}{h_{i, t-1}}\right)\right]$

where $w_{\mathrm{i}, \mathrm{t}}$ is the share of total labour income paid to group $i$ in period $t$, the weight used is the average of $w_{i, t}$ and $w_{i, t-1}$, and the income shares sum to one. The logged changes are then used to create an index where the first quarter of the time series, Q1 1993, equals 100 . The use of data from the current and previous period to weight the change in hours is a feature of Törnqvist indices, making them more current or representative measures. The index is also a widely used form in economic analysis, particularly with regard to quality-adjusted labour measures (Bell et al 2005). A more detailed discussion of index numbers can be found in Goodridge (2007).

The difference between the Törnqvist index and an unadjusted index of hours is referred to throughout the article as 'labour composition'. 


\section{Box $1 \quad$ Labour characteristics}

The choice of labour characteristics involves a trade-off between parsimony and data availability, and the objective of capturing significant developments in labour inputs to production. None of the following characteristics represent labour quality in and of themselves, but only as dimensions of the income-share weights.

\section{Age}

Age is included as a proxy for work experience. Although imperfect, as it takes no account of periods of unemployment or inactivity, the assumption is that older workers tend be more productive due to their greater experience, and therefore receive greater compensation for their labour. Alternatively, it has been suggested that younger workers may be more dynamic and innovative than their older counterparts (Bell et al 2005). However, if this is true in some cases, then provided labour markets are competitive, these workers will be paid their marginal product and growth in hours will be weighted accordingly.

\section{Gender}

Gender is chosen because of the persistent pay differential that exists between males and females, even after holding other factors constant. Although not a driver of quality change itself, it may represent hidden characteristics such as an increased tendency to take career breaks or to fulfil part-time posts that are not as well paid. Therefore, this complements, or improves, the use of age as a proxy for work experience, as well as helping to explain the pay differential. However, if the pay differential instead reflects discrimination, then the assumption that workers are paid their marginal product is violated, resulting in hours growth being weighted incorrectly and the quality adjustment carrying a downward bias. This is a weakness of the model.

\section{Education}

This is measured as the highest qualification attained and used as a proxy for skills. Qualifications either act as a signal of ability to employers or they provide the knowledge for specific job requirements. This characteristic is the primary driver of the index. Due to the increasing prevalence of higher degrees and their growing association with higher pay, they are included as a stand-alone category.

\section{Industry}

Although primarily included for the observation of industry trends and the use of QALI in industry-level MFP, this category also helps capture inherent differences in skill and productivity that exist between industries. The industry categories chosen are broad partly because industry is self-reported in the LFS, leading to inaccuracy of response, and also because of small sample sizes for some sectors. 


\section{Data source}

The main data source for QALI is the Labour Force Survey (LFS). The LFS is a continuous household survey that covers approximately 53,000 households every quarter. It provides data on the volume of hours worked, and contains series for educational attainment, industry, gender and age, plus pay data, which are used to carry out the quality adjustment. Although the LFS became quarterly in 1992, questions about the respondent's income were not asked until 1993, so the QALI series begins in the first quarter of 1993.

\section{Scaling}

QALI's consistency with other data series, particularly the National Accounts and ONS headline productivity measures, is important for its use in other types of productivity calculation such as growth accounting. To achieve this external consistency, various components of QALI are scaled to ONS aggregates. Specifically:

- gross weekly pay is scaled to National Accounts industry level 'Compensation of Employees' (CoE)

- actual hours worked are scaled to industry level productivity hours ${ }^{3}$

- total jobs are scaled to industry level productivity jobs ${ }^{4}$

The first adjustment improves the consistency of the LFS-based data with National Accounts income measures. While the LFS only provides information on wages and salaries, CoE also includes bonuses and income-in-kind and, as such, is a more complete indicator of total remuneration. Additionally, as with other household surveys, LFS micro-data include proxy responses, missing responses and inaccurate data. Respondents have particular difficulty recalling their pre-tax income or bonuses accurately; scaling the data helps overcome these issues. It should be noted that the scaling up of gross weekly pay does not impact on QALI for individual industries, but the relative weights of industries will change and so will whole economy and market sector QALI as a result.

CoE only covers remuneration of employees; the earnings of the self-employed are recorded as mixed income, which accounts for both the returns to capital and labour. Ideally, QALI would split mixed income to give labour compensation for the self-employed. However, it is not possible to do this at present. Aggregating LFS employees' wages with LFS imputed self-employed wages and scaling to $\mathrm{CoE}$ is the next best methodology available under current data constraints.

Scaling the jobs and hours data to the headline labour productivity jobs and hours series, which use superior business survey-based industry breakdowns, improves consistency and also helps to overcome partly the inaccuracies in the LFS industrial breakdown. 


\section{Data issues}

The inclusion of the self-employed poses an issue as wages for the self-employed are not recorded in the LFS or any other survey. This is because self-employed people remunerate themselves for a combination of labour and entrepreneurial effort, without distinguishing between the two. In producing QALI, LFS data on the compositional characteristics of the self-employed are used, and the wages of employees with similar characteristics are used as an approximation for the labour income of the self-employed. This is likely to be an over-estimate, but the method used is the most appropriate for such a detailed dataset (Turvey 2009).

To measure labour's true input to production as accurately as possible, no restrictions have been placed on outliers, and actual hours rather than usual hours are used because, conceptually, it is the former that need to be measured.

\section{Comparison with previous release}

When performing the quality adjustment there is an inevitable trade-off between the different categories due to constraints imposed by the sample size of the LFS. In particular, a judgement needs to be made whether to prioritise the main compositional categories (education, age and gender) or focus on the industrial breakdown. This release uses the same compositional breakdown initiated by the previous release (Turvey, Goodridge and Franklin 2010).

The compositional and industrial breakdowns used are summarised in Table 1.

\section{Table $1 \quad$ Quality adjustment categories}

\begin{tabular}{|c|c|c|c|c|}
\hline Education & Age & Gender & Industry* & Industry description \\
\hline Masters and doctorates (NVQ6) & $16-29$ & Male & ABCE & $\begin{array}{l}\text { Agriculture, hunting and forestry; fishing; } \\
\text { mining and quarrying; utilities }\end{array}$ \\
\hline First and other degrees (NVQ5) & $30-49$ & Female & $\mathrm{D}$ & Manufacturing \\
\hline $\begin{array}{l}\text { Certificates of education or equivalent } \\
\text { (NVQ4) }\end{array}$ & $50+$ & & $\mathrm{F}$ & Construction \\
\hline $\begin{array}{l}\text { A levels or trade apprenticeships } \\
\text { (NVQ3) }\end{array}$ & & & G & Wholesale and retail trade \\
\hline $\begin{array}{l}\text { GCSEs or equivalent (NVQ2, NVQ1, } \\
\text { other qualifications) }\end{array}$ & & & $\mathrm{H}$ & Hotels and restaurants \\
\hline \multirow[t]{5}{*}{ No qualifications } & & & 1 & Transport, storage and communication \\
\hline & & & $\mathrm{J}$ & Financial intermediation \\
\hline & & & $\mathrm{K}$ & Real estate, renting and business activities \\
\hline & & & LMN & $\begin{array}{l}\text { Public administration and defence; education; } \\
\text { health and social work }\end{array}$ \\
\hline & & & $\mathrm{OPQ}$ & Other social and personal services \\
\hline
\end{tabular}

* Standard Industrial Classification 2003 
By producing results for ten industries, other compositional categories are necessarily more limited. For example, there are only three age categories. Despite the expected pay differential between, say, workers aged 16-19 and workers aged 26-29, this limitation is necessary if enhanced industrial detail is sought (particularly for growth accounting analysis).

\section{Table 2 Relative remuneration per hour, 2009}

Whole economy $=100$

\section{Industry}

ABCE: Agriculture etc; mining and quarrying; utilities

D: Manufacturing

F: Construction

G: Wholesale and retail trade

$\mathrm{H}$ : Hotels and restaurants

I: Transport, storage and communications

J: Financial intermediation

$\mathrm{K}$ : Real estate, renting and business activities

\section{Gender}

Females

Males

\section{Age}

16-29 years

\section{Education}


Table 2 gives an indication of the relative remuneration per hour in 2009 of the compositional categories recorded in Table $1^{5}$. This is extracted from the LFS micro-data and is not scaled to any National Accounts or other productivity series. The table highlights the variance in pay across the quality-adjustment categories. Not surprisingly, some QALI categories, like working in financial intermediation or having a higher degree, provide more returns to labour input than others, on average.

The table does not necessarily foreshadow the QALI results; for example, remuneration per hour in hotels and restaurants is very low relative to the whole economy average, but this does not necessarily imply that QALI comparisons between the two will yield similar results. For example, QALI for whole economy will change if labour supply moves between hotels and restaurants and other industries. And QALI for hotels and restaurants will change if the share of labour input in hotels and restaurants moves between gender or age group or mix of qualifications. The table simply shows the importance of accounting for different compositional differences when calculating quality-adjusted labour inputs.

\section{Results}

Figure 1 compares an index of unadjusted hours worked across the whole economy, based on LFS micro-data, with labour composition. These are the two components that make up QALI ${ }^{6}$.

\section{Figure 1 Whole economy QALI}

$1993 \mathrm{Q} 1=100$

Index points

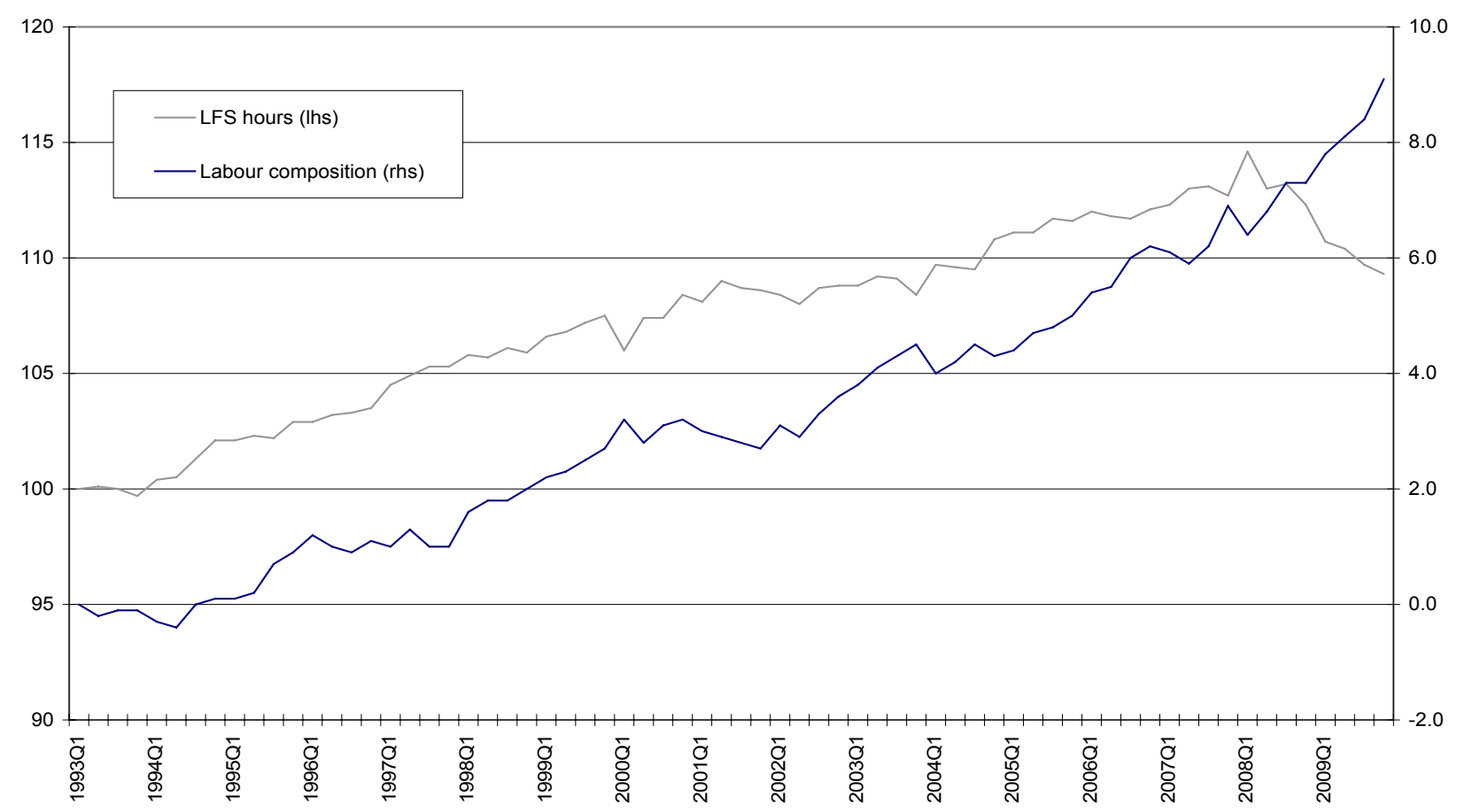

Source: Office for National Statistics 
Labour composition has been rising very steadily over the period. Hours have also been rising for most of the period but since Q1 2008 they have fallen back sharply. With labour composition increasing and less hours being worked this implies that the employed workforce is moving toward higher remunerated QALI categories, on average. The increase in labour composition combined with falling hours over the recession suggests that low-skilled workers suffered proportionately more than those with higher skill levels.

\section{Quality-adjusted labour input by industry}

Figures 2 to 11 show results for the ten industries outlined in Table 1. In each case, an unadjusted hours index is presented alongside labour composition (the difference between QALI and the unadjusted series).

Unadjusted hours in agriculture, forestry, fishing, mining and utilities (Figure 2) fell between 1993 and 2002 but began to rise, albeit erratically, since this period. Labour composition has shown no upward trend since 2004. There appears to be little or no adverse impact from the recession on this industry; in fact, hours increased over 2008 and 2009.

In the manufacturing sector (Figure 3), unadjusted hours have fallen sharply since 1998, with the rate of decline notably increasing over the recession. Labour composition has shown consistent growth over the period although it dipped slightly over the recession. Outside of the service sector, construction (Figure 4) has experienced the fastest growth in hours, but the slowest growth in labour composition. This may reflect limited scope to substitute towards higher skilled workers in the construction sector. In 2009, construction experienced the sharpest fall in unadjusted hours of all industries under analysis, an indication of the severe impact of the downturn on this industry. By contrast, labour composition increased substantially over the same period, suggesting that high skilled workers in this industry have fared the recession better than their low skilled counterparts.

Unadjusted hours in wholesale and retail trade (Figure 5) were at close to 1993 levels by the end of 2009. Labour composition, on the other hand, grew consistently over the same time period. Such a pattern highlights the importance of quality adjusting labour: a simple hours index (the blue line) hides the notable increase in labour quality in this industry over the time period in general and over the recession in particular.

Unadjusted hours for hotels and restaurants (Figure 6) grew by 30 per cent since 1993, the second fastest growth for all industries under analysis. However, hours in this industry have fallen by 13 percentage points between 2008 Q1 and 2009 Q4. Until the beginning of 2006, labour composition was in fact negative, indicating a weakening skill profile relative to the base period. Labour composition grew strongly between 2006 and 2008, before levelling off. The significant jump in labour composition between 2006 and 2008 is not explained by one single composition characteristic, but is a combination of age and gender interactions; the shift, however, has little to do with higher qualification levels.

The trend in unadjusted hours and labour composition in transport, storage and communication (Figure 7) is similar to that of wholesale and retail trade (Figure 5). Relative to 1993, there was a pure 'quality' effect of nine index points in 2009. 
Figure 2 Agriculture, forestry, fishing; mining and quarrying; utilities (ABCE)

$1993 \mathrm{Q} 1=100$

Index points

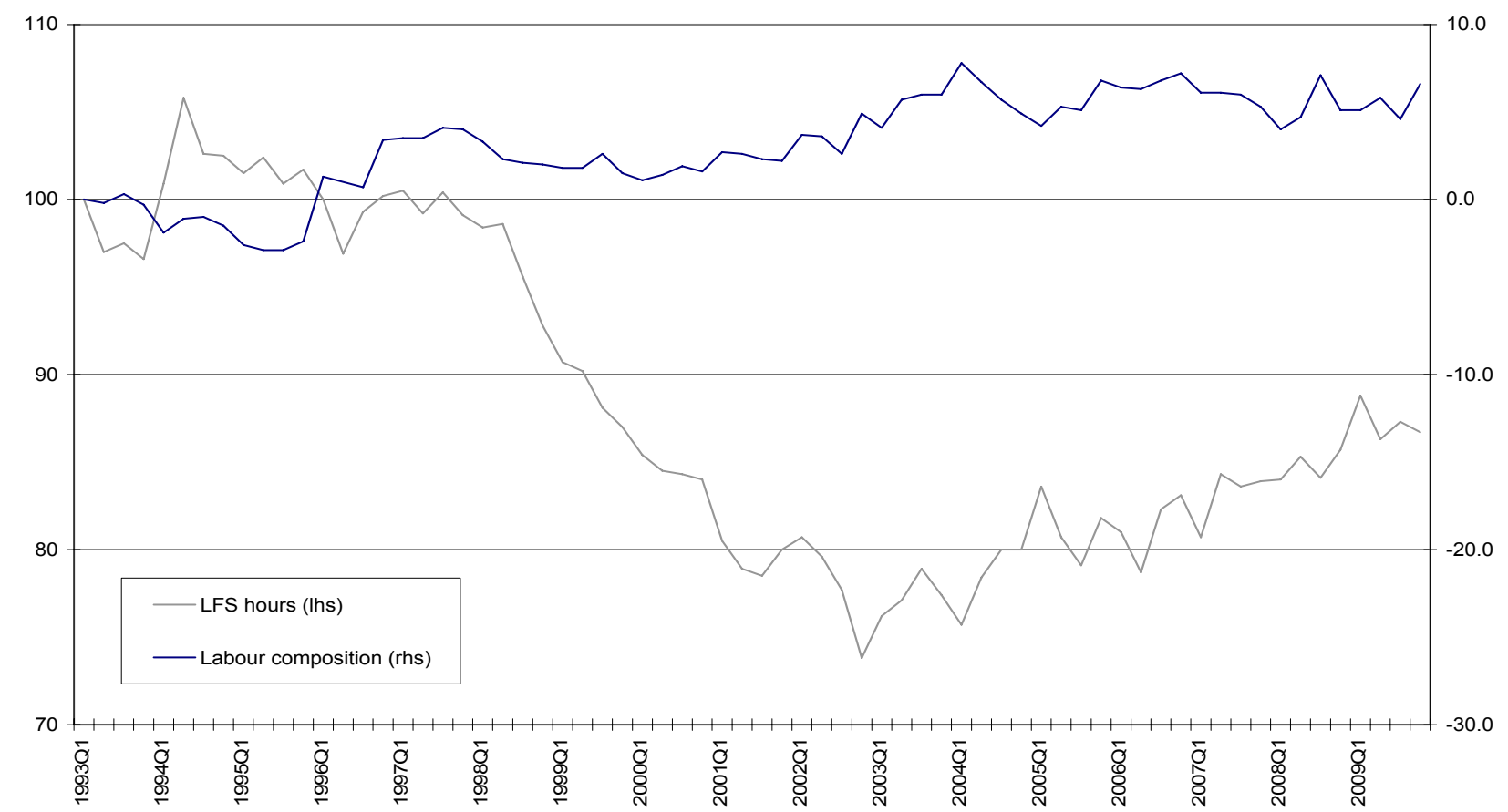

Source: Office for National Statistics

\section{Figure $3 \quad$ Manufacturing (D)}

$1993 \mathrm{Q} 1=100$

Index points

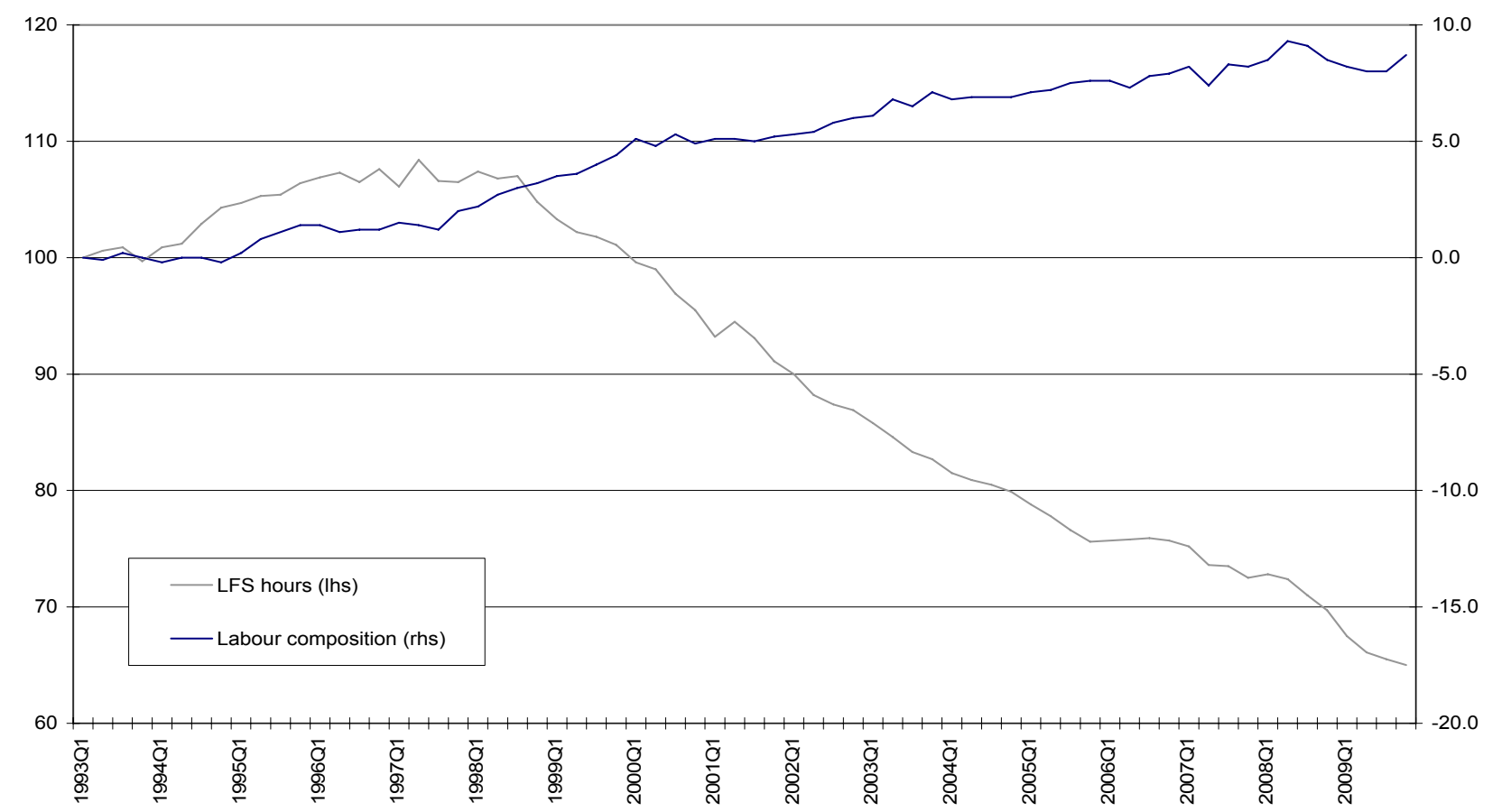

Source: Office for National Statistics 
Figure 4 Construction (F)

$1993 \mathrm{Q} 1=100$

Index points

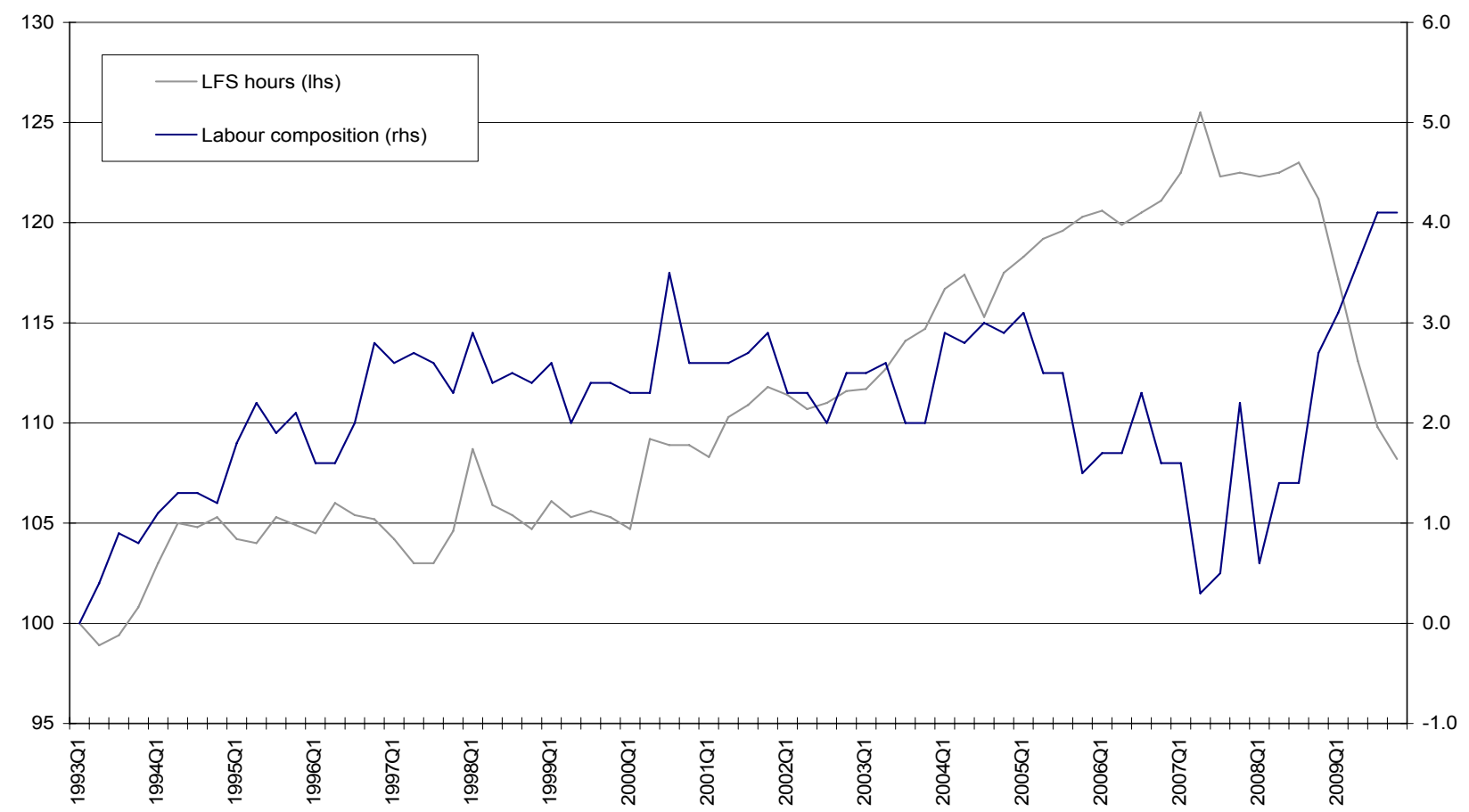

Source: Office for National Statistics

Figure 5 Wholesale and retail (G)

1993 Q1 = 100

Index points

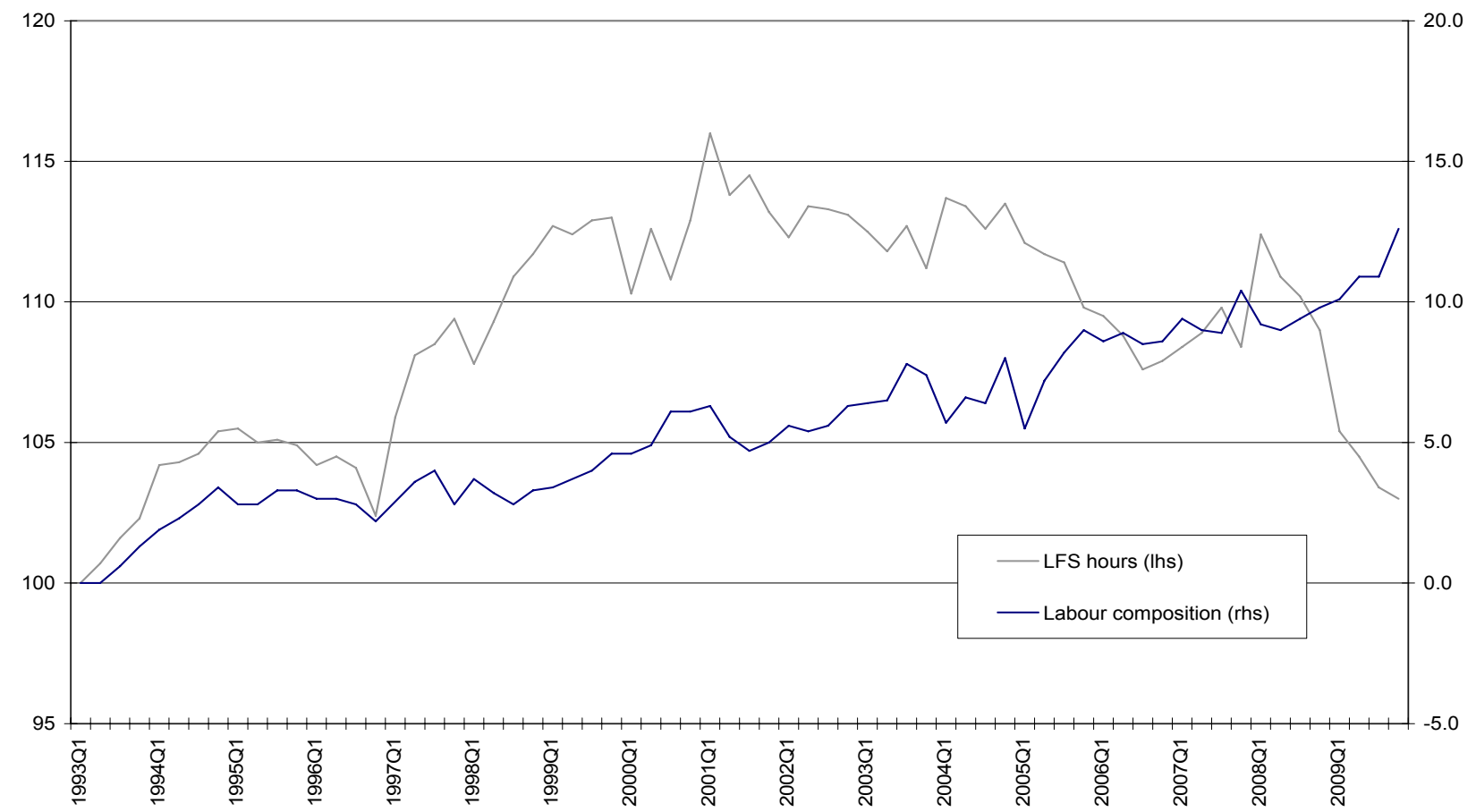

Source: Office for National Statistics 
Figure $6 \quad$ Hotels and restaurants $(\mathbf{H})$

$1993 \mathrm{Q} 1=100$

Index points

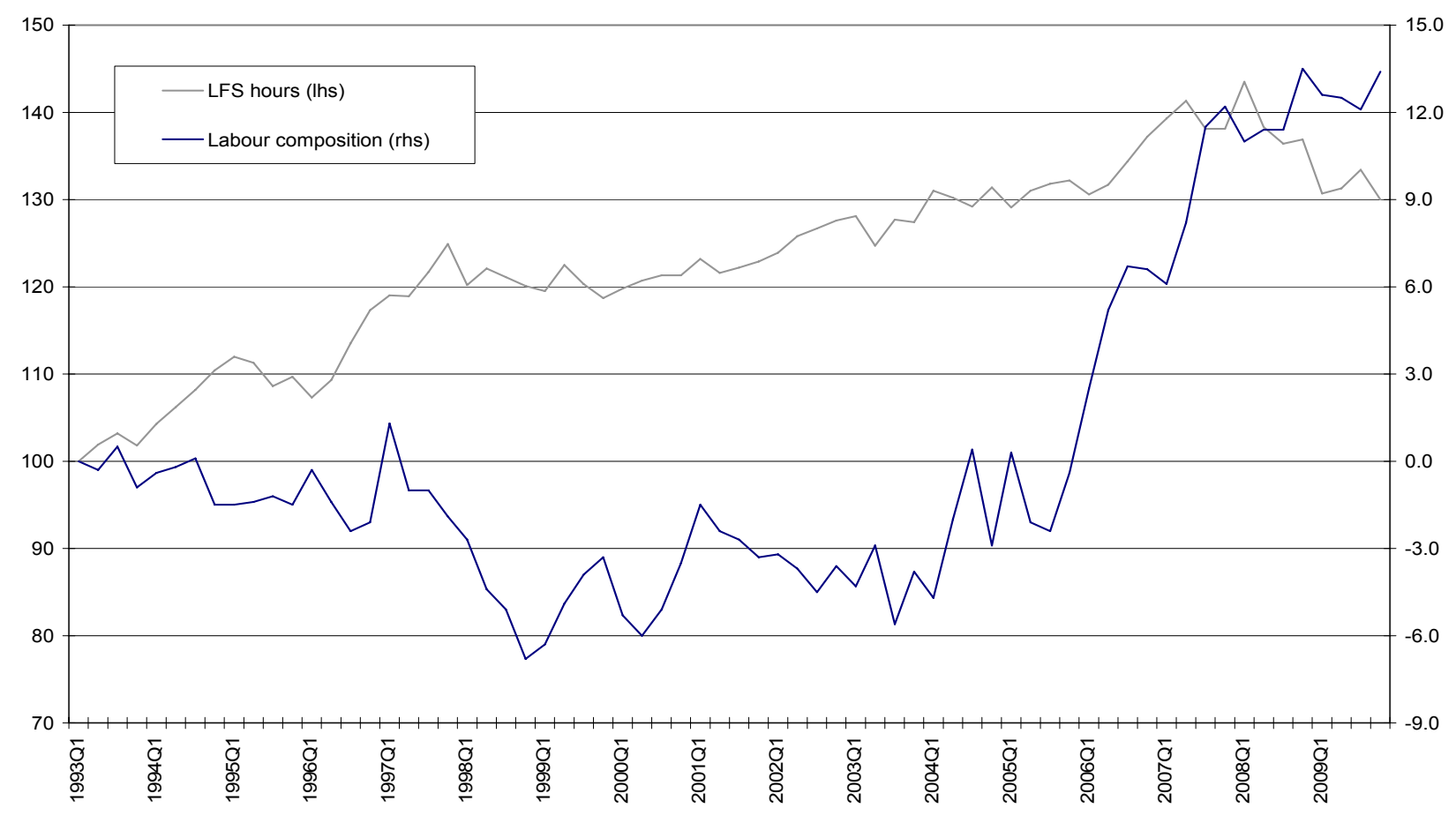

Source: Office for National Statistics

Figure $7 \quad$ Transport, storage and communication (I)

1993 Q1 = 100

Index points

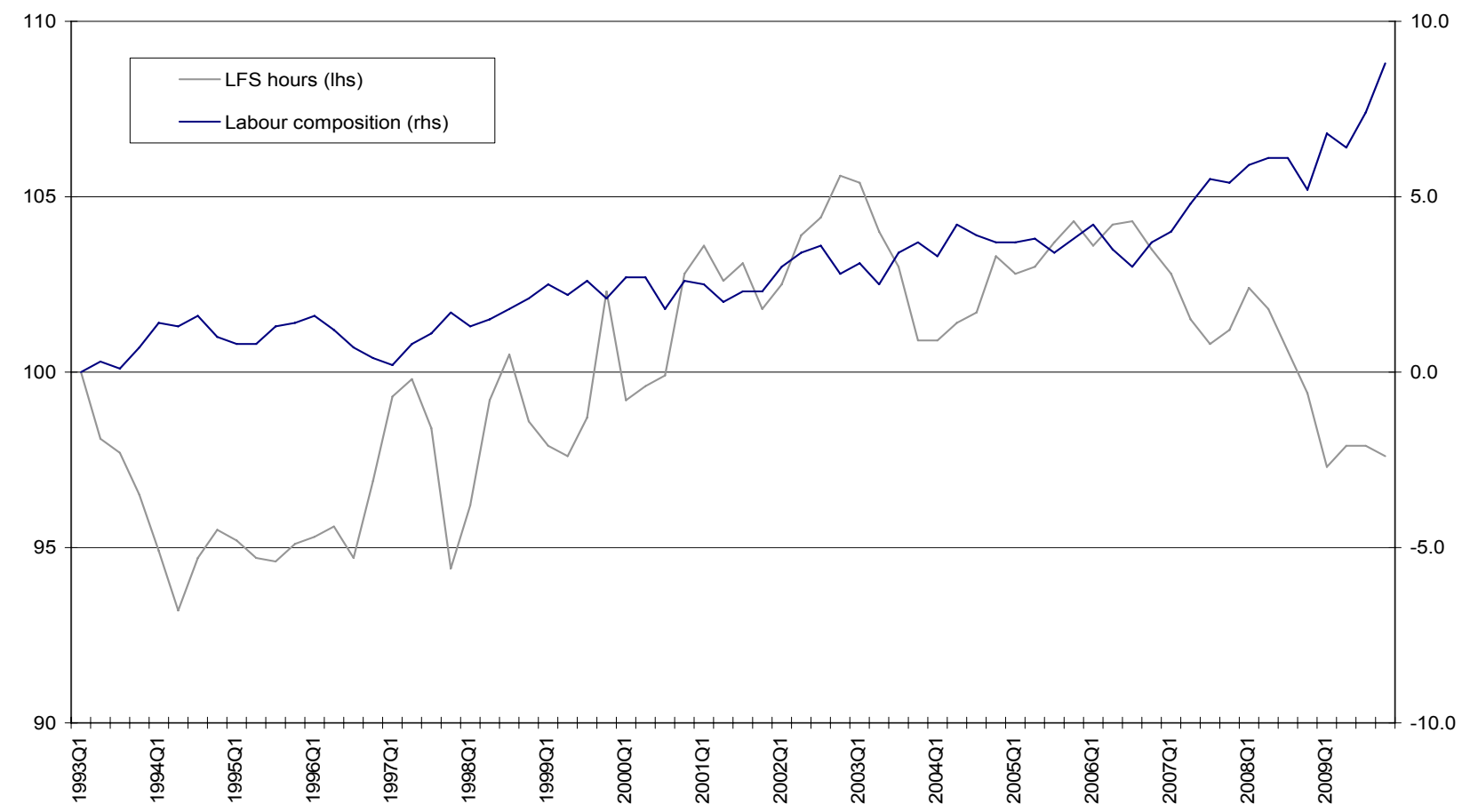

Source: Office for National Statistics 
Unadjusted hours in financial intermediation (Figure 8) actually grew during the first half of the recession, before falling back sharply in 2009. Considering the importance of this industry to the wider economy, there has not been significant growth in hours since 1993, and it is perhaps surprising that hours have not fallen over the recession. Labour composition, however, has grown faster over the entire period than in any other industry. The proportion of QALI (obtained by adding labour composition to the unadjusted hours series) that is driven by quality is the highest for any industry. Labour composition remained on an upward trend over the recession except for a slight dip in the last quarter of 2009.

Growth in unadjusted hours for real estate, renting and business activities (Figure 9) was greater than in any other section: it grew by 68 percentage points, relative to the first quarter of 1993. However, labour composition has only been positive since 2002, that is to say the qualityadjustment has only led to a higher overall labour input since that time. In 2009 Q4 labour composition rose to its highest since the series began: 8.5 index points. The recession does not appear to have impacted on labour composition (although its contribution to QALI is quite small anyway).

The trends in both industries are reflective of their importance to the wider economy over this period. In real estate, renting and business activities, hours worked grew very quickly as the volume of labour supply increased to meet demand, while the financial sector attracted many highly-skilled workers in order to add value. Both suffered over the recession but, from a labour input perspective, real estate, renting and business activities is recovering more quickly.

\section{Figure $8 \quad$ Financial intermediation (J)}

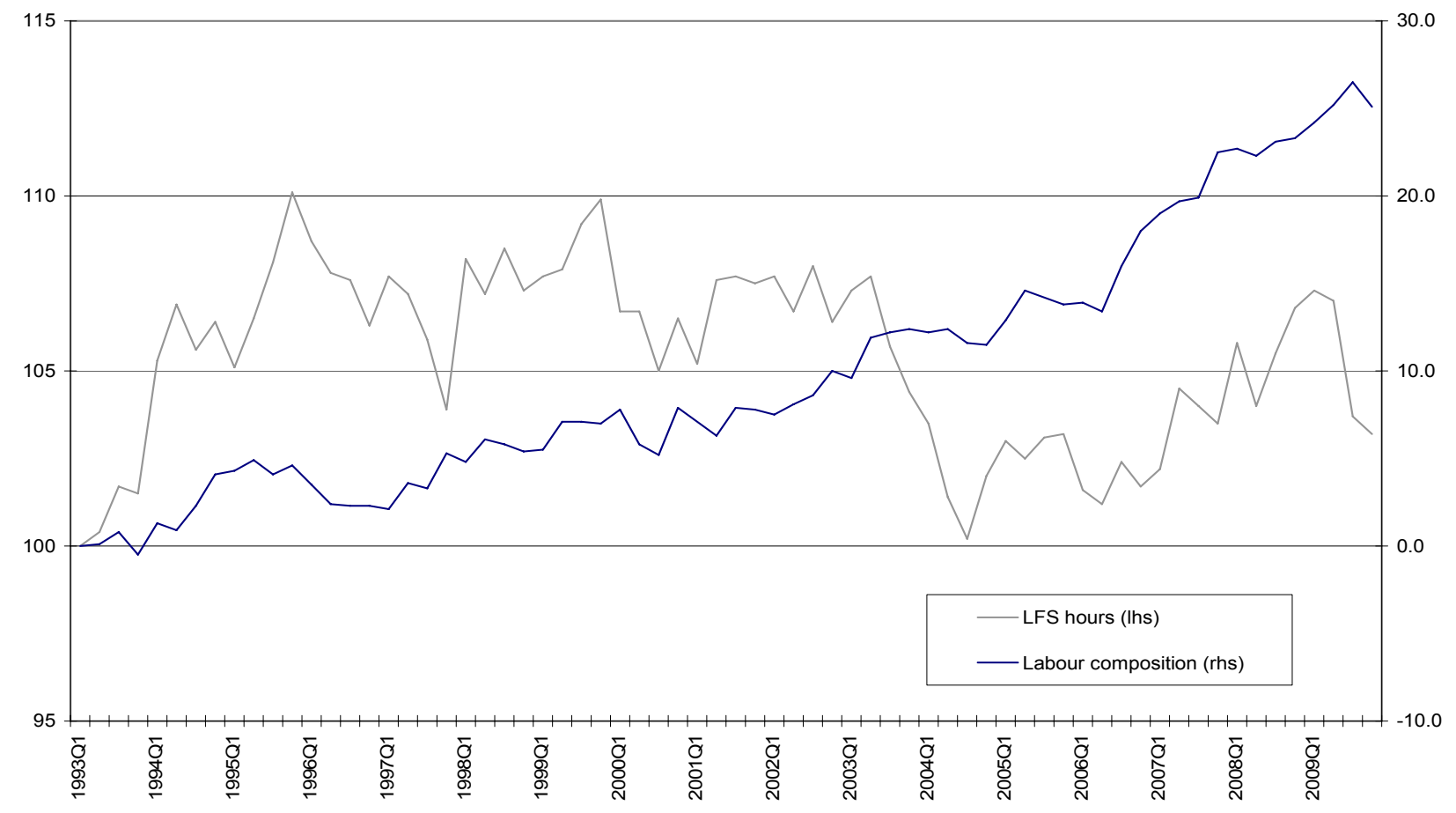

Source: Office for National Statistics 


\section{Figure 9 Real estate, renting and business activities (K)}

$1993 \mathrm{Q} 1=100$

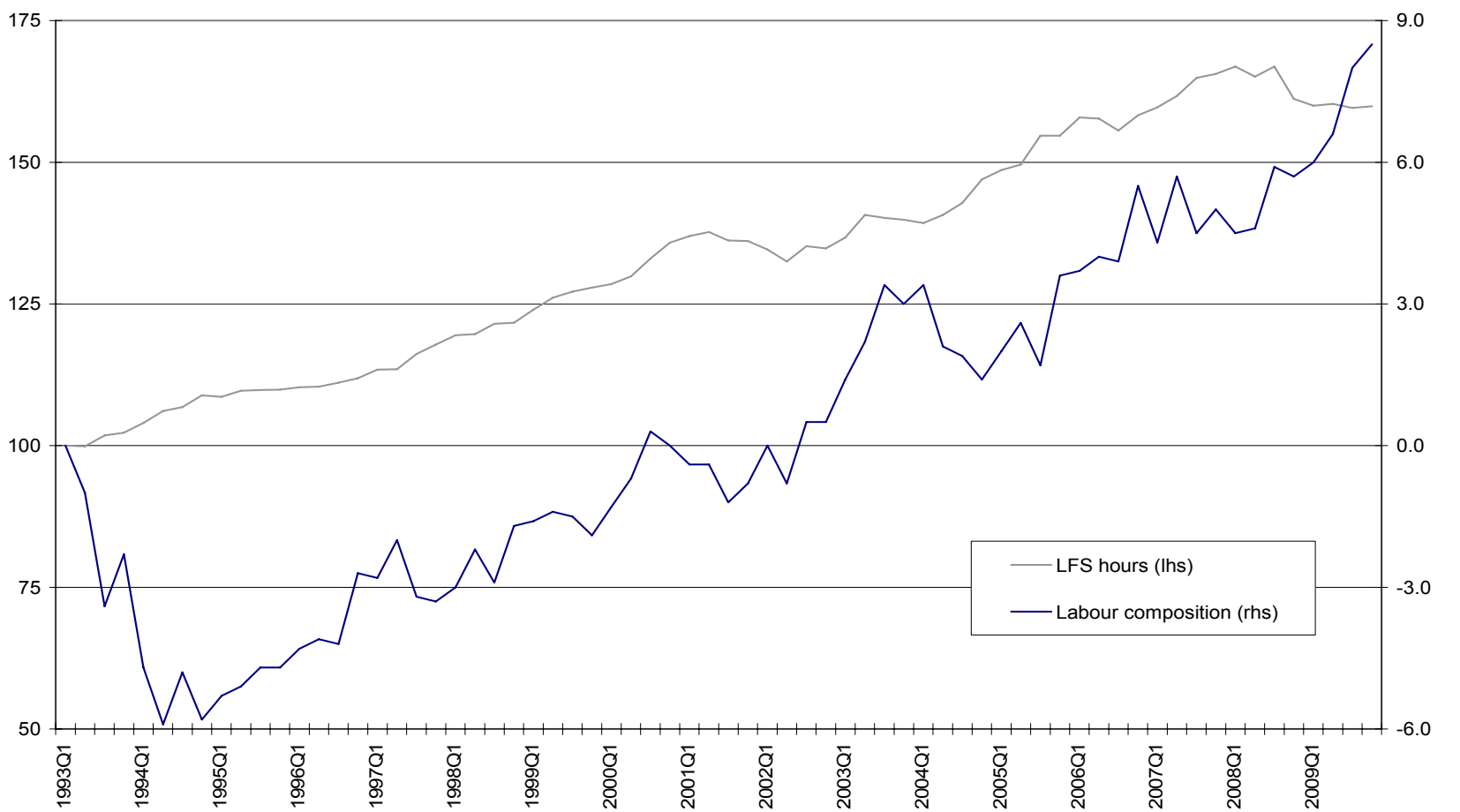

Source: Office for National Statistics

Public administration, education and health (Figure 10) has seen a strong increase in both labour composition and unadjusted hours over the recession. This result is unique to this industry. Other personal and social services (Figure 11) also exhibited strong growth in labour composition over the recession. Over the period as a whole, personal and social services experienced an increase in labour composition that was only slightly below that of financial intermediation. The output of these services (in gross value added terms) is, however, smaller than that of financial intermediation services.

Figure 12 presents labour composition and an index of unadjusted hours for the market sector. These series begin in the first quarter of 1994, the earliest date the variables used to filter out nonmarket sector responses can be found in the LFS. The trends are very similar to those of the whole economy (Figure 1). However, labour composition for the whole economy is slightly higher than the market sector throughout the entire period. Considering the impact of quality-adjusting labour in the predominantly non-market public services (Figure 10), this result is not surprising. Market sector hours have fallen by more over the recession than whole economy, again reflecting the impact of public services on the whole economy aggregate.

The above analysis by industry focuses on labour composition by gender, age and qualification; however it is possible to run the analysis by focusing on one of these compositional elements and weighting it by the others and by industry of employment. For example, analysis by qualification computes QALI weighted by gender, age and industry of employment; QALI by age weights by qualification, gender and industry; and QALI by gender weights by qualification, age and industry. 
Figure 10 Public services (LMN)

$1993 \mathrm{Q} 1=100$

Index points

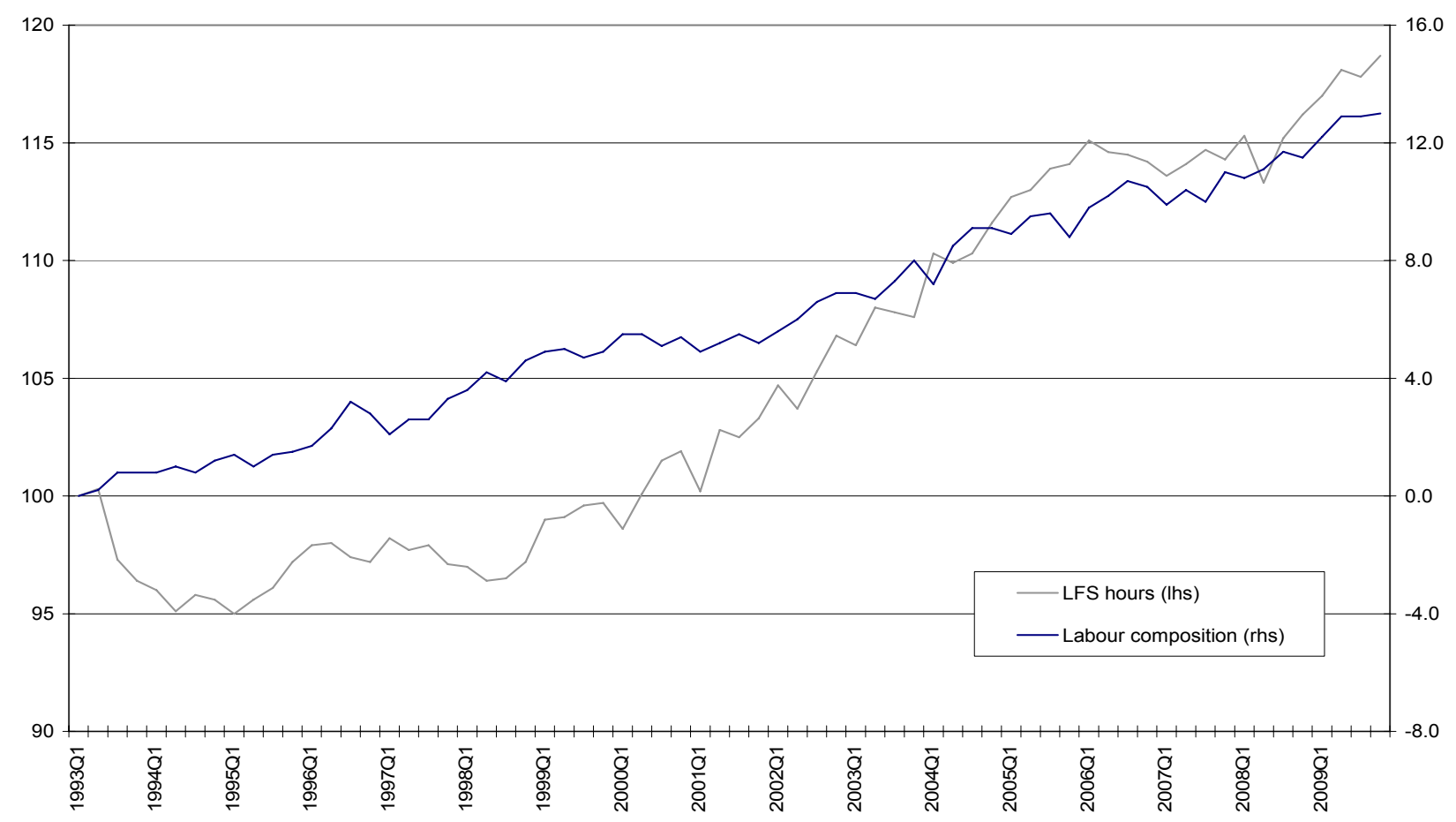

Source: Office for National Statistics

Figure 11 Other services (OPQ)

1993 Q1 = 100

Index points

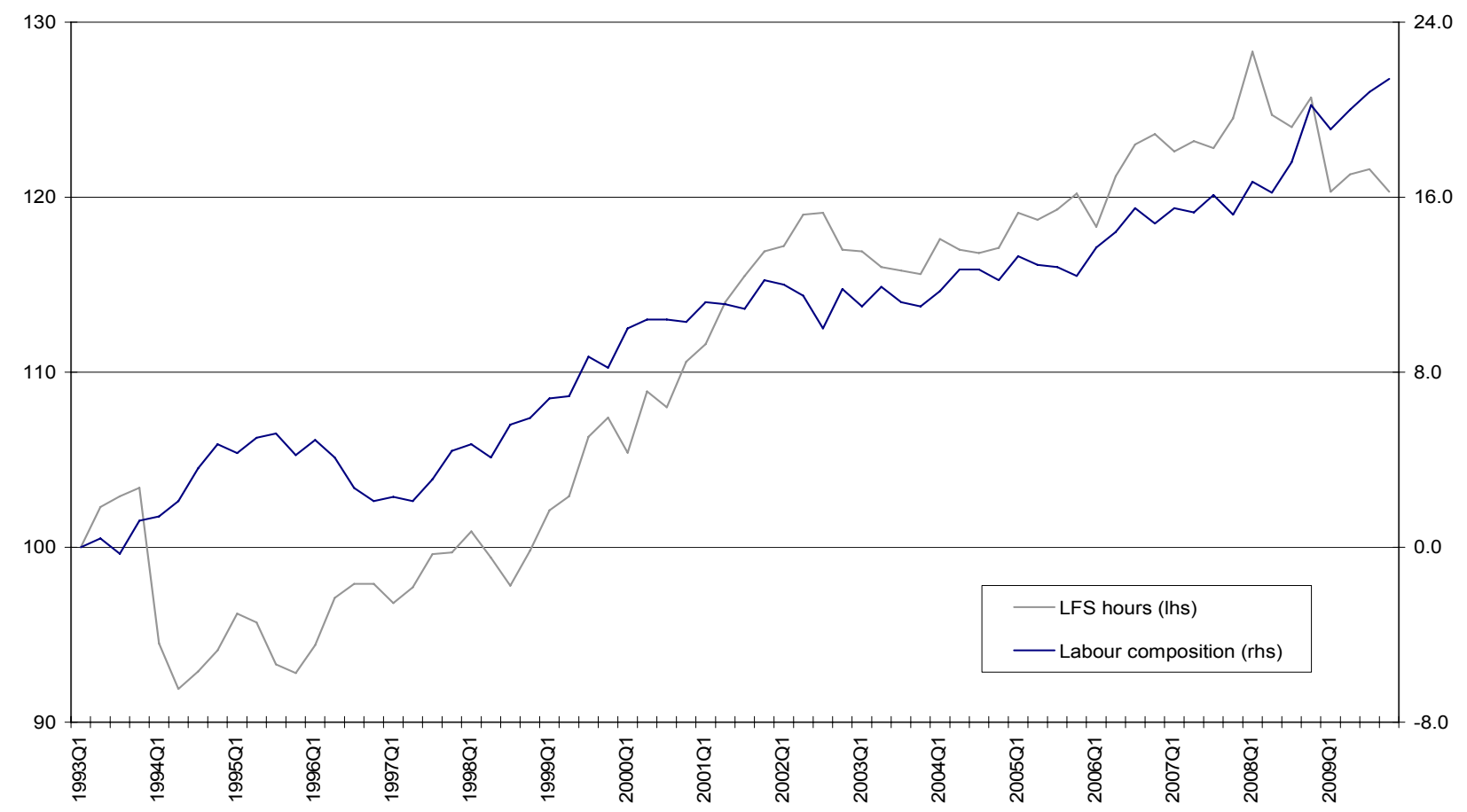

Source: Office for National Statistics 


\section{Figure 12 Market sector}

$1994 \mathrm{Q} 1=100$

Index points

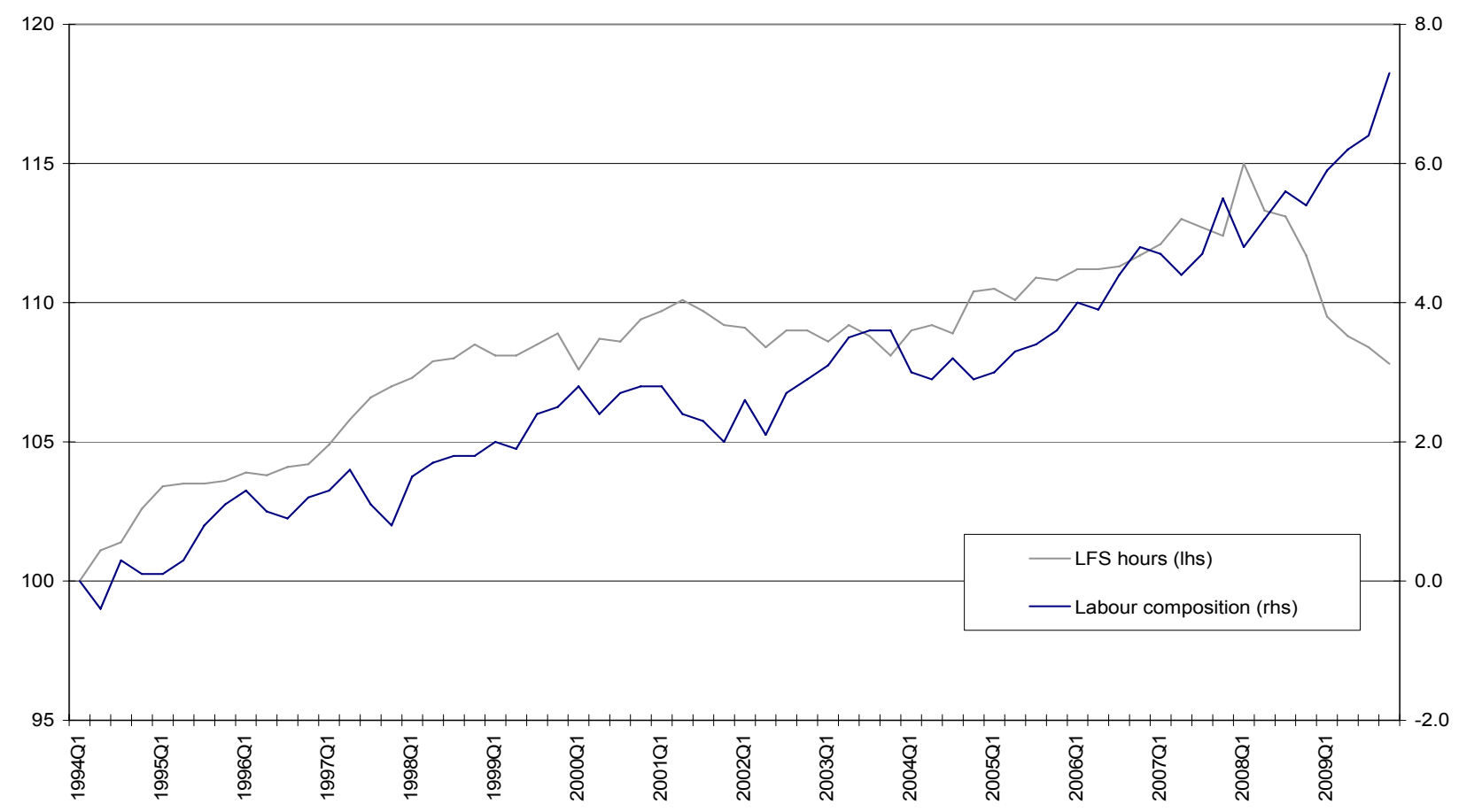

Source: Office for National Statistics

\section{Quality-adjusted labour input by education}

Figures 13 and 14 show estimates of unadjusted hours and labour composition by highest qualification ${ }^{7}$.

Unadjusted hours for masters and doctorates grew at a much faster rate than any other qualification level (Figure 13): this series increased by 300 percentage points over the entire period. But the same cohort also saw rapid decline in their labour composition: it decreased by 19 percentage points between 1993 and 2009 (Figure 14). This suggests those with higher qualifications do not automatically take up high-paying jobs. It could also be related to the other labour characteristics of workers with these qualifications; for example their age, gender and industry of employment could result in lower earnings, which would impact on the labour composition result. Table 2 demonstrates that although relative remuneration for this cohort is high, with such high growth in the volume of labour it is inevitable that at the margin there will be some workers earning less, particularly if this cohort has a young age profile or increasingly works in low-paying industries.

Combining the two results from Figures 13 and 14, the rapid increase in the volume of labour taken with the overall fall in labour composition for this group indicates an over-qualification of labour input for these workers. However, over the recession, labour composition for masters and doctorates increased, suggesting that higher skill levels offer, on average, the best protection during economic downturns. 
Figure 13 Unadjusted hours by qualification level

$1993 \mathrm{Q} 1=100$

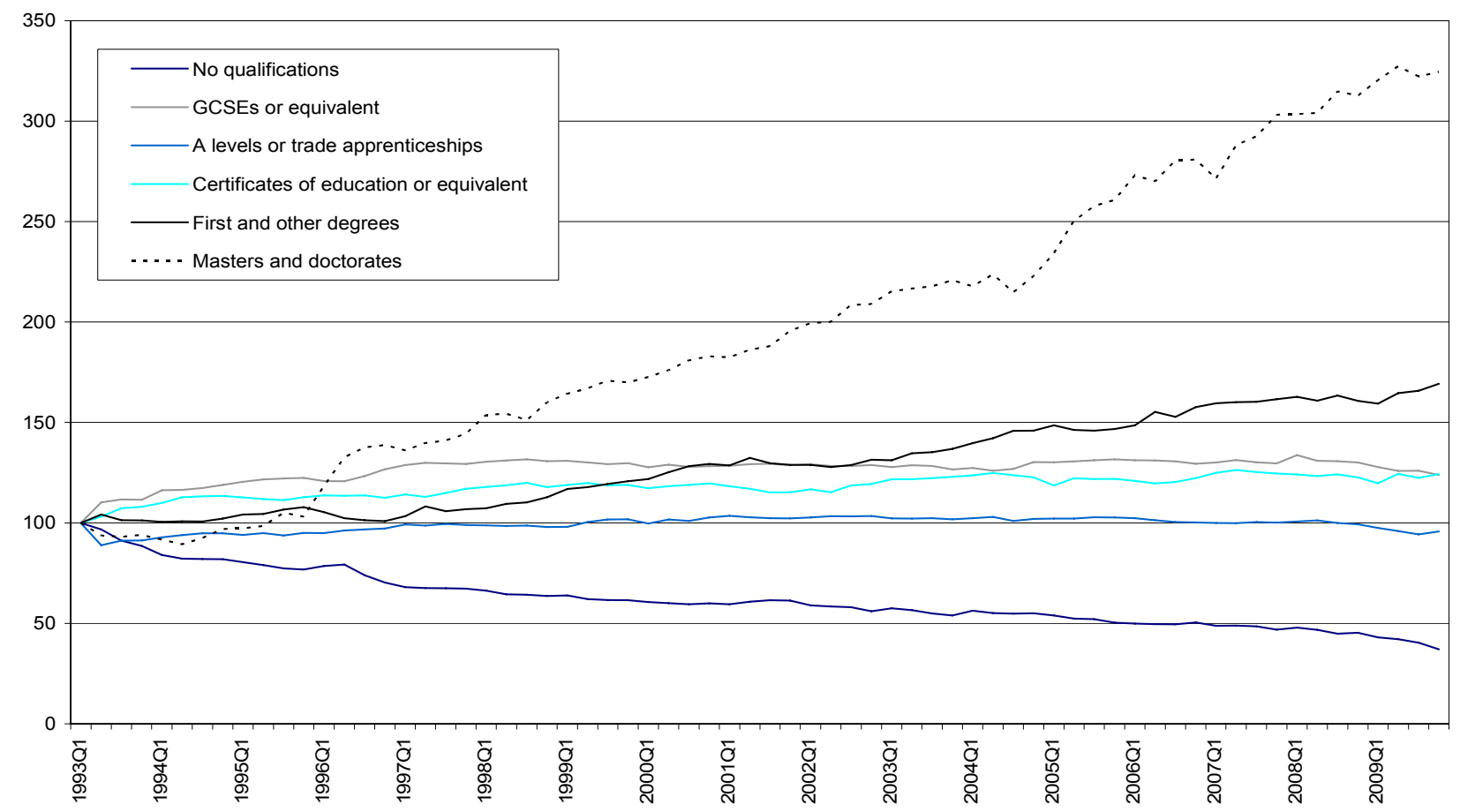

Source: Office for National Statistics

Figure 14 Labour composition by qualification level Index points

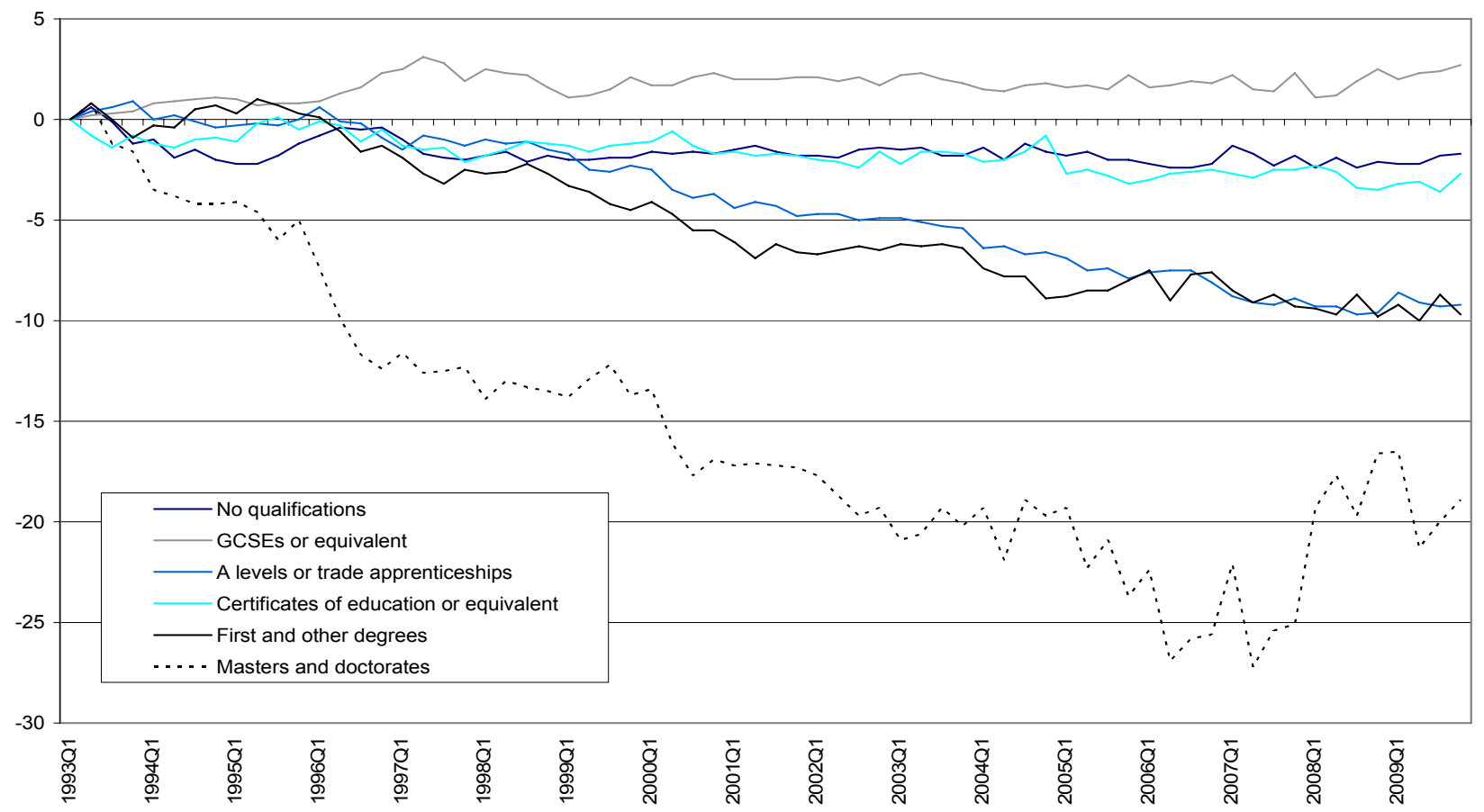

Source: Office for National Statistics 
Only those with no qualifications saw their hours decline over the entire period, with the recession not appearing to accentuate the overall trend of decline by much. Those with GSCEs or equivalent were the only cohort to see positive labour composition throughout the period; this could be related to their age profile as well as the industry they work in. Those with first or other degrees saw their hours increase slightly and labour composition stabilise over 2008 and 2009. Similarly to those with masters and doctorates, this suggests that the higher qualified are better protected during recessions.

\section{Quality-adjusted labour input by age}

Figures 15 and 16 present indices of unadjusted hours and labour composition by age group. The unadjusted hours series increased by the most for the over-50s, reflecting their increased labourforce participation between 1993 and $2009^{8}$. Labour composition growth for this group easily exceeded that of the other two age groups. It is clear from looking at both indices that the over-50s were not so adversely affected by the economic downturn.

On the eve of the recession, unadjusted hours for workers aged 16-29 were back at 1993 levels, but an 11 point fall was recorded from Q1 2008 to Q4 2009, which highlights how much the recession disproportionately impacted on this cohort ${ }^{9}$. Labour composition rose over the period, but not by a substantial amount.

\section{Figure 15 Unadjusted hours by age}

$1993 \mathrm{Q} 1=100$

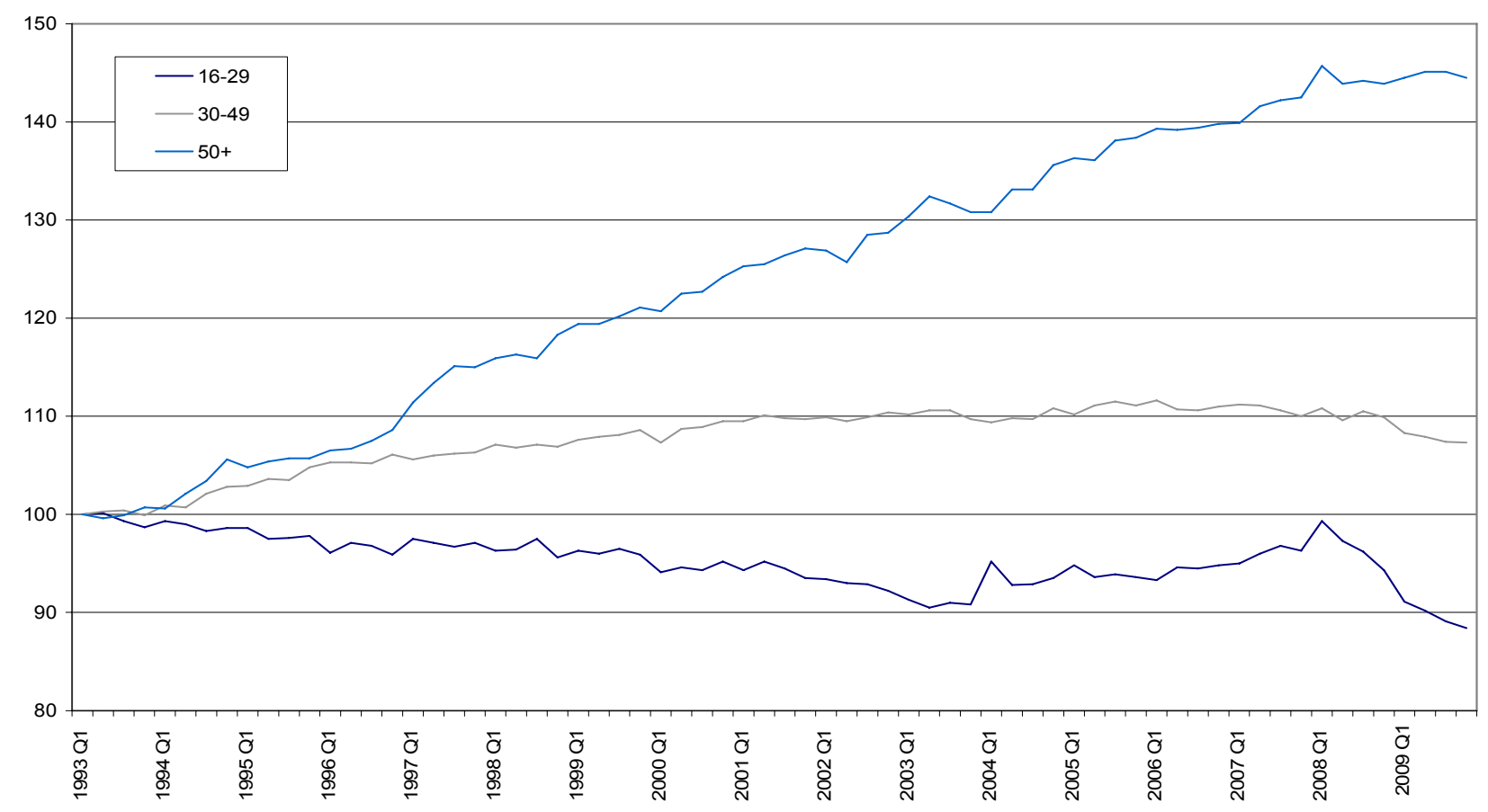

Source: Office for National Statistics 


\section{Figure 16 Labour composition by age}

Index points

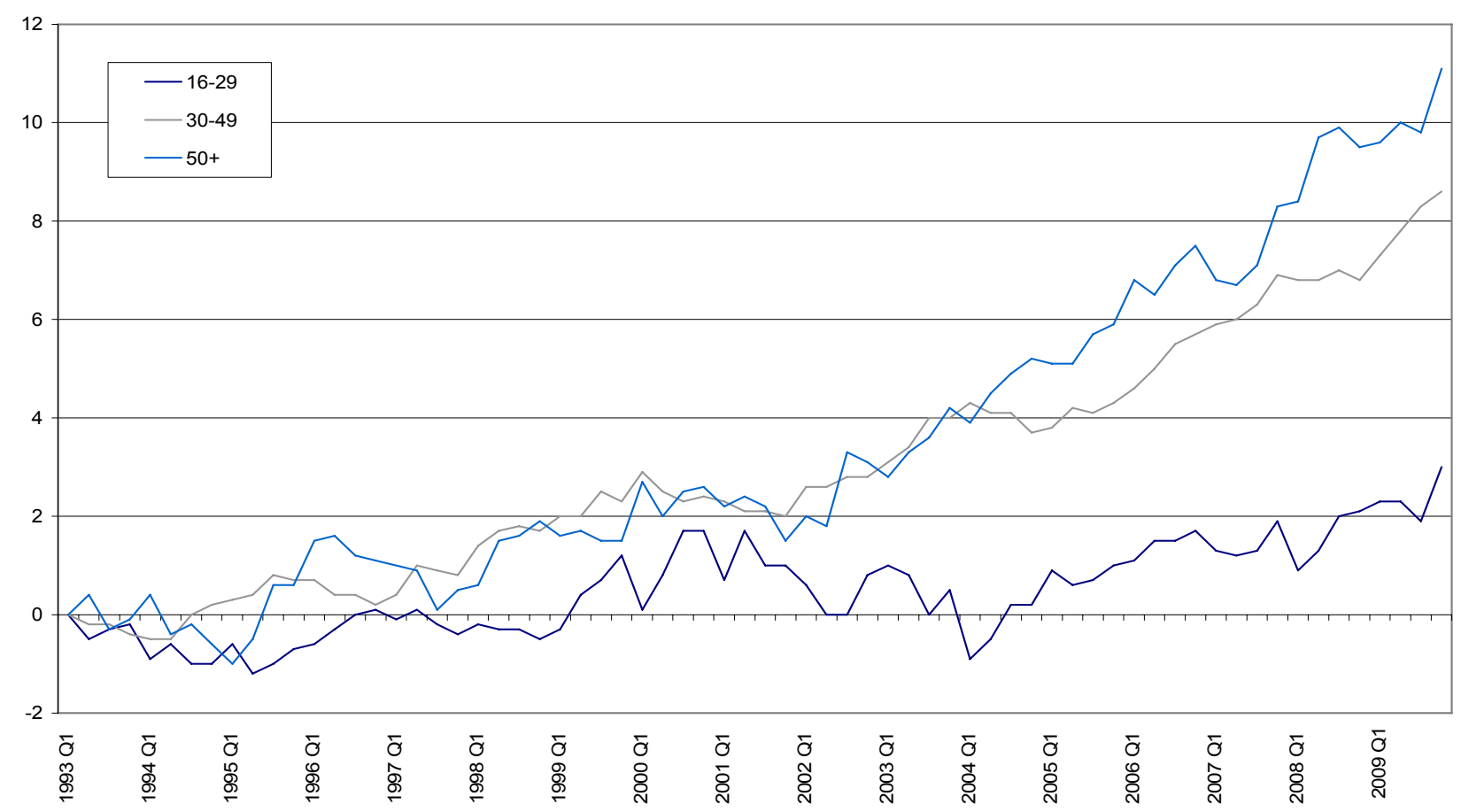

Source: Office for National Statistics

Labour composition increased steadily for workers aged 30-49, and unadjusted hours also displayed an upward trend until 2006, although it was far weaker than that experienced by the over-50s. It has declined since then, with the recession having only a marginal impact on this rate of decline.

The increase in labour composition for all age groups over the recessions suggests a substitution away from the less skilled (as reflected in relative remuneration) in all age groups, but especially for those under 30 years.

\section{Quality-adjusted labour input by gender}

Figures 17 and 18 compare estimates of unadjusted hours and labour composition for men and women. The gender variable is included in QALI in order to compensate for the fact that age is only a rough proxy for experience; using a gender variable compensates for this as empirically men and women have different working patterns, with women showing a greater tendency for career breaks and part-time work.

The unadjusted hours series (Figure 17) highlights the pure volume effect of increased participation by women in the labour market. While the graph indicates that, relative to 1993, both men and women have been similarly affected by the recession, the headline labour market statistics highlight that, on a levels basis, men were affected more by the recession ${ }^{10}$. 
Figure $17 \quad$ Unadjusted hours by gender

$1993 \mathrm{Q} 1=100$

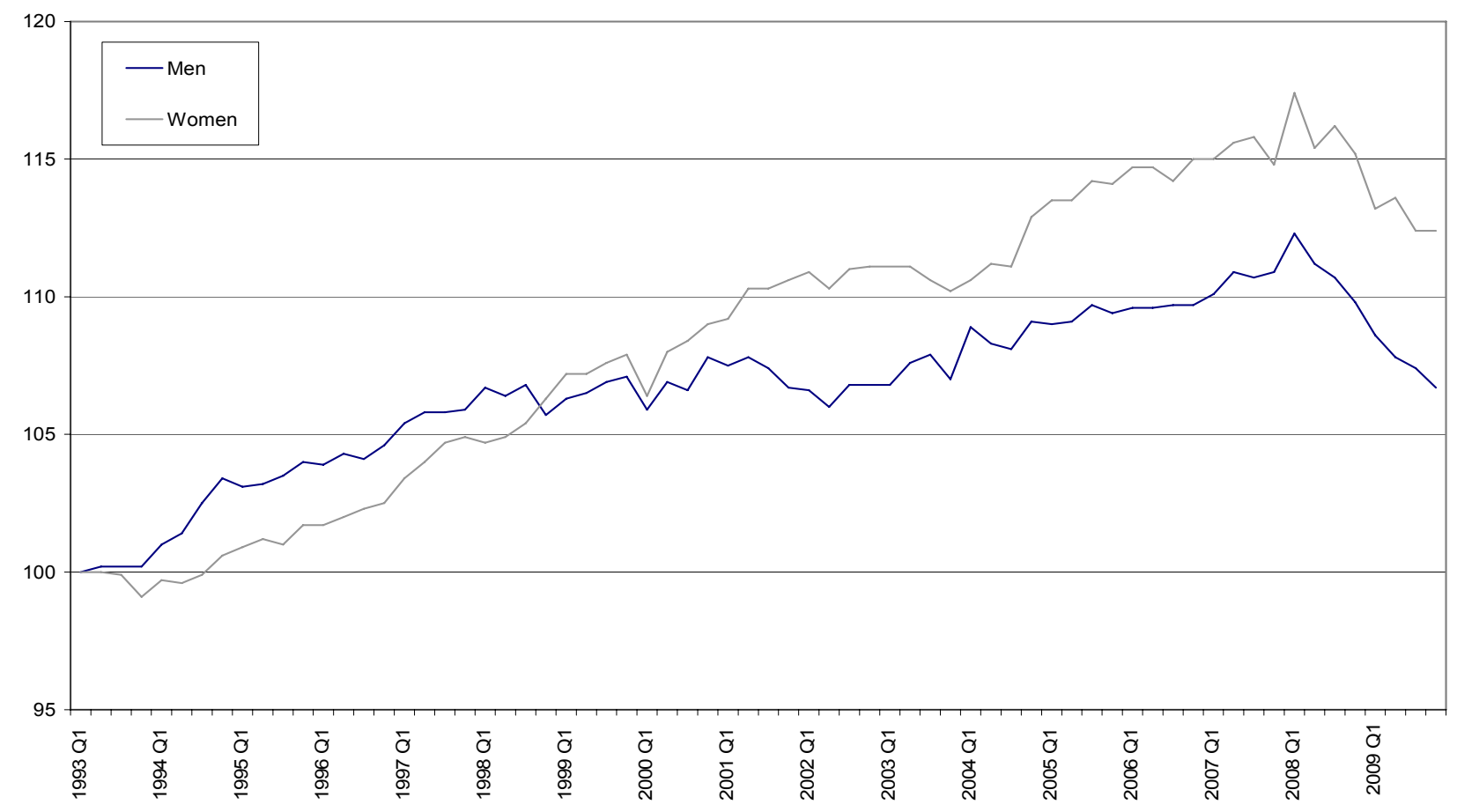

Source: Office for National Statistics

Figure 18 Labour composition by gender Index points

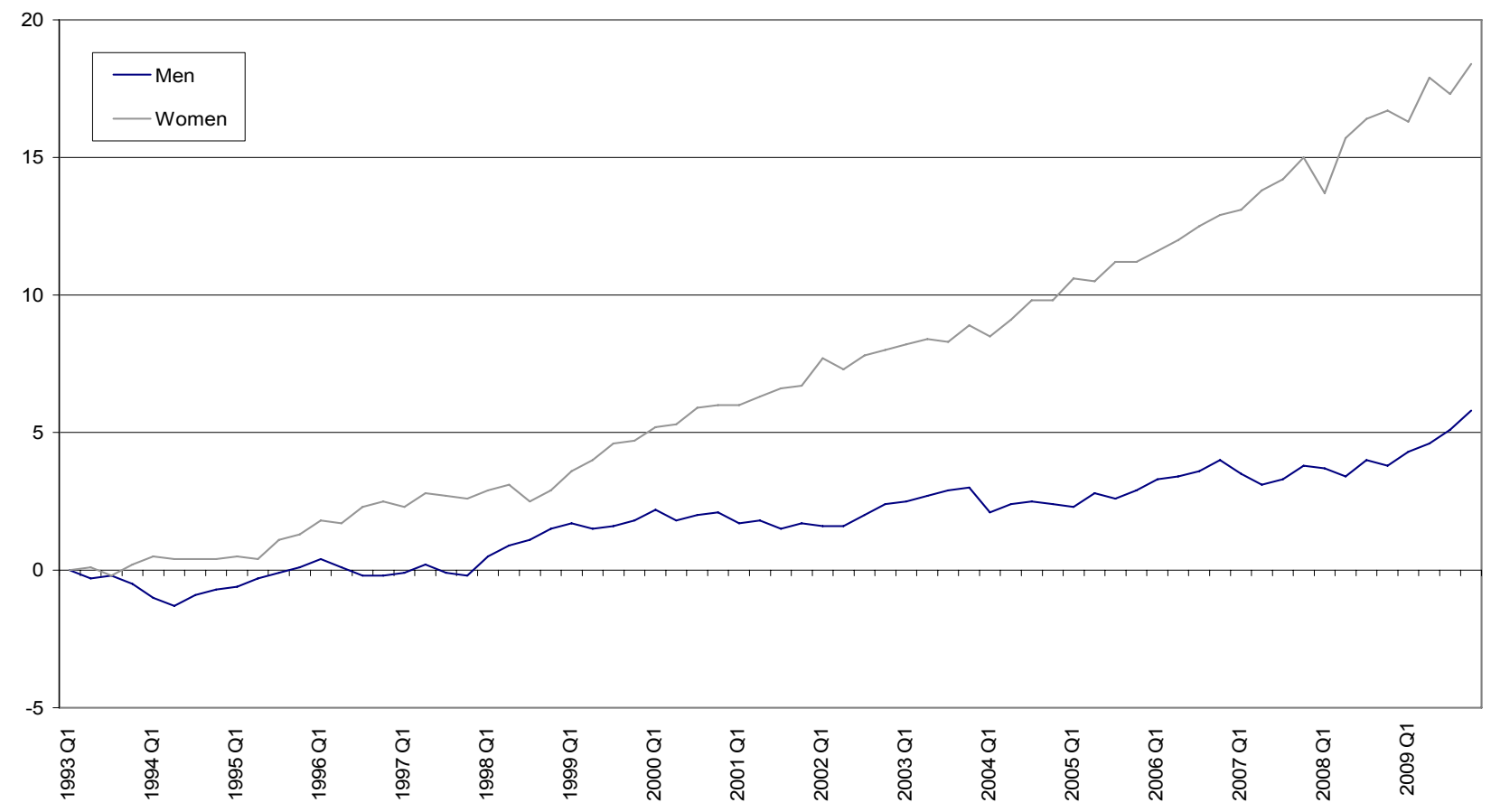

Source: Office for National Statistics 
For labour composition (Figure 18), growth for women compared to men is striking. Reasons for the difference include the increased participation of women in the labour market and improving educational attainment for women relative to men. It is also possible that it picks up some effects of equal pay legislation mandating a convergence between male and female compensation. To the extent that it shows the existence (but weakening) of discrimination in the labour market, it is demonstrating the weakness of using pay as a proxy for marginal productivity.

\section{EU KLEMS backcasting}

One advantage of the current compositional breakdown is that it aligns QALI quite closely with the 'labour services' series generated by the EU KLEMS project ${ }^{11}$. The quality-adjustment in EU KLEMS has identical age and gender categories to QALI but fewer education categories: it uses three categories compared to six in QALI. This allows the EU KLEMS data to be produced at a greater industrial breakdown. Like QALI, EU KLEMS assumes that, other things equal, the compensation per hour of a self-employed person is equal to that of an employee. EU KLEMS also employs the Törnqvist index, but on an annual basis.

It is possible to map the EU KLEMS industries to QALI industries because the former is produced at a more disaggregated level. QALI industries, that is the ten industries listed in Table 1, can be obtained by aggregating particular EU KLEMS industries together.

Conceptually 'labour services' and QALI are similar, and in their derivation at industry level it is only the educational categories that differ significantly. As the two are so similar, it is reasonable to use the growth profile of the 'labour services' series, which extends back to 1970, to backcast QALI on an annual basis. Furthermore, the educational differences can be assumed to narrow the further into the past we go. 1993 is taken as the base year, so that a comparison can be drawn with the quarterly analysis in the previous section.

Table 3 examines the differences between the QALI system and the EU KLEMS system by looking at average annual growth rates between the years of overlap, 1993 to 2007 . The difference is greatest for unadjusted hours in agriculture, forestry, fishing, mining and utilities (ABCE) and other services (OPQ). In general, the differences in labour composition are smaller than the differences in hours ${ }^{12}$. For the majority of industries the differences are small and suggest the results produced by the two systems are similar enough to make the backcasting a plausible exercise.

At the whole economy level (Figure 19), the pattern in hours growth prior to 1993 is quite different to that from 1993 onward, with the former showing a smooth upward trend until the most recent recession. It can clearly be seen that larger falls in hours were recorded for previous recessions in the early 1980s and early 1990s. Labour composition, however, has risen quite steadily between 1970 and 2009, despite the changing economic cycles, with the average annual growth rate increasing since 1993. 


\section{Table 3 QALI and EU KLEMS: Average annual growth rates, 1993- 2007}

Percentages

\begin{tabular}{lcccccc}
\hline & \multicolumn{3}{c}{ Labour Composition } & \multicolumn{3}{c}{ Unadjusted Hours } \\
\cline { 2 - 6 } & QALI & EU KLEMS & Difference & QALI & EU KLEMS & Difference \\
\cline { 2 - 6 } Whole economy & 0.4 & 0.6 & $\mathbf{- 0 . 2}$ & 0.9 & 0.8 & $\mathbf{0 . 1}$ \\
ABCE: Agriculture etc; mining and quarrying; & & & & & \\
utilities & 0.5 & 0.2 & $\mathbf{0 . 3}$ & -1.1 & -2.9 & $\mathbf{1 . 8}$ \\
D: Manufacturing & 0.7 & 0.9 & $\mathbf{- 0 . 2}$ & -2.1 & -2.1 & $\mathbf{0 . 0}$ \\
F: Construction & 0.0 & 0.3 & $\mathbf{- 0 . 3}$ & 1.5 & 0.8 & $\mathbf{0 . 7}$ \\
G: Wholesale and retail trade & 0.6 & 0.5 & $\mathbf{0 . 0}$ & 0.5 & 0.4 & $\mathbf{0 . 2}$ \\
H: Hotels and restaurants & 0.5 & 0.7 & $\mathbf{- 0 . 2}$ & 2.3 & 1.6 & $\mathbf{0 . 7}$ \\
I: Transport, storage and communications & 0.3 & 0.4 & $\mathbf{- 0 . 1}$ & 0.3 & 0.4 & $\mathbf{- 0 . 1}$ \\
J: Financial intermediation & 1.3 & 1.2 & $\mathbf{0 . 1}$ & 0.2 & 0.8 & $\mathbf{- 0 . 6}$ \\
K: Real estate, renting and business activities & 0.3 & 0.8 & $\mathbf{- 0 . 4}$ & 3.5 & 3.6 & $\mathbf{- 0 . 1}$ \\
$\begin{array}{l}\text { LMN: Public admin and defence; education; } \\
\text { health and social work }\end{array}$ & 0.6 & 0.7 & $\mathbf{- 0 . 1}$ & 1.1 & 1.3 & $\mathbf{- 0 . 2}$ \\
OPQ: Other social and personal services & 0.8 & 0.8 & $\mathbf{0 . 0}$ & 1.4 & & $\mathbf{- 1 . 5}$ \\
\hline
\end{tabular}

Source: Office for National Statistics

Figure 19 Whole economy backcasting

$1993=100$

Index points

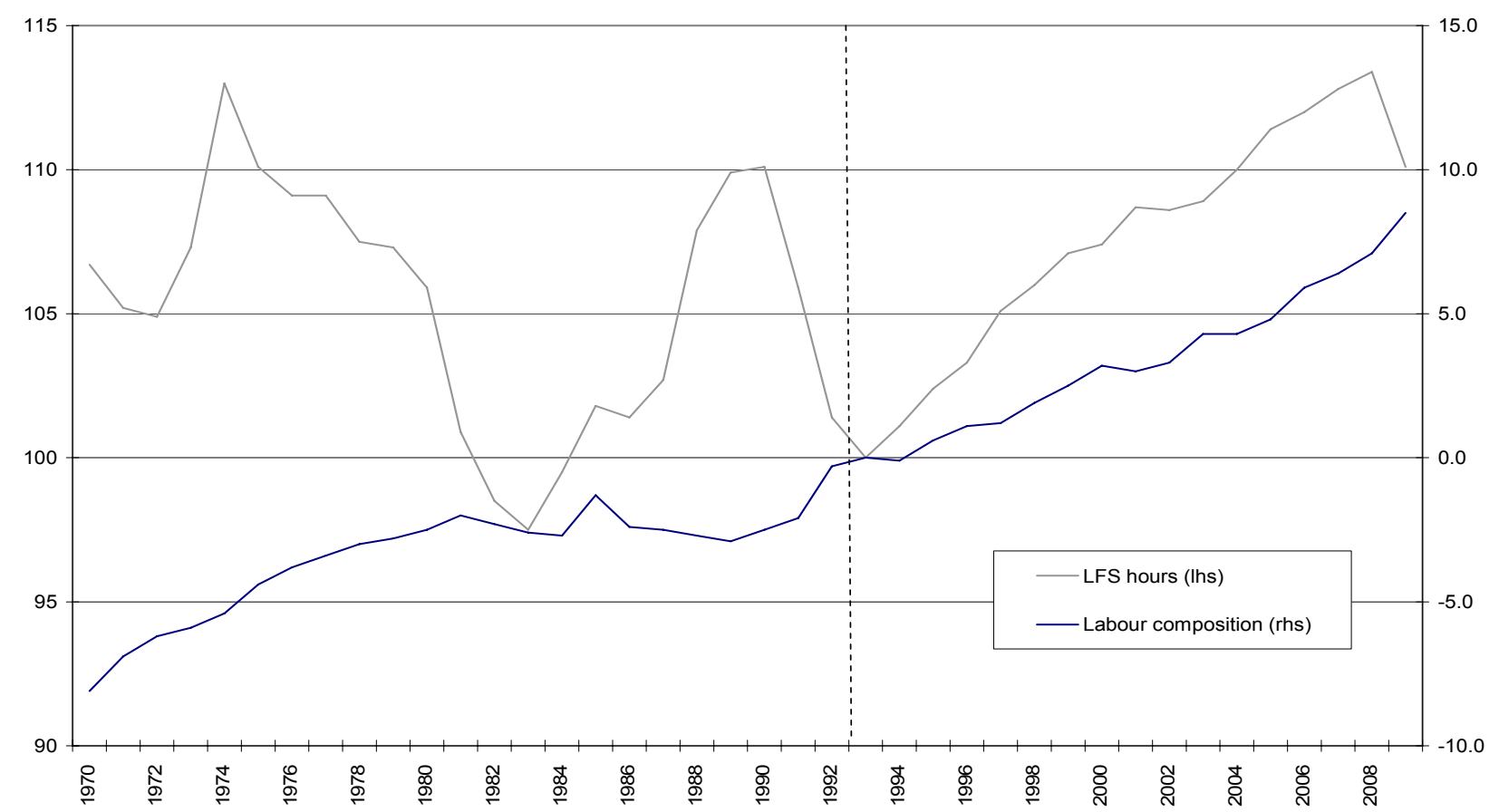

Source: Office for National Statistics 
In Table 4, the annual growth rates for the periods 1970-1993 and 1993-2009 are averaged in order to provide a picture of movements in unadjusted hours and labour composition across the entire period.

\section{Table $4 \quad$ Average annual growth rates, 1970-1993 and 1993-2009}

Percentages

\begin{tabular}{|c|c|c|c|c|}
\hline & \multicolumn{2}{|c|}{$1970-1993$} & \multicolumn{2}{|r|}{ 1993-2009 } \\
\hline & Hours & Labour Composition & Hours & Labour Composition \\
\hline Whole economy & -0.2 & 0.3 & 0.5 & 0.5 \\
\hline ABCE: Agriculture etc; mining and quarrying; utilities & -3.0 & -0.6 & -1.0 & 0.2 \\
\hline D: Manufacturing & -2.8 & 0.2 & -2.6 & 0.7 \\
\hline F: Construction & -0.5 & 0.2 & 0.6 & 0.1 \\
\hline G: Wholesale and retail trade & 0.5 & 0.0 & 0.1 & 0.6 \\
\hline $\mathrm{H}$ : Hotels and restaurants & 1.8 & -0.1 & 1.3 & 0.6 \\
\hline I: Transport, storage and communications & -0.7 & 0.0 & -0.1 & 0.4 \\
\hline J: Financial intermediation & 2.4 & 0.4 & 0.2 & 1.3 \\
\hline K: Real estate, renting and business activities & 3.1 & 1.4 & 2.8 & 0.4 \\
\hline $\begin{array}{l}\text { LMN: Public admin and defence; education; health and } \\
\text { social work }\end{array}$ & 1.2 & 0.7 & 1.1 & 0.6 \\
\hline OPQ: Other social and personal services & 2.0 & 1.4 & 1.3 & 1.0 \\
\hline
\end{tabular}

Source: Office for National Statistics

Agriculture, forestry, fishing, mining and utilities (ABCE) has seen a turnaround in labour composition between the two periods, with positive annual growth rates, on average, from 1993 onward compared to negative average growth rates previously. The rate of decline in hours slowed substantially in the later period, possibly due to the effects of earlier privatisation in mining and utilities fading. In manufacturing (D), hours have been declining throughout the entire period but at a slower rate since 1993. Labour composition has risen at a much higher average annual rate since 1993, which suggests that employment in high-paying manufacturing jobs has increased relative to low-paying jobs, and the extension of this is that the skill profile in manufacturing has improved markedly over the time period.

With the exception of transport, storage and communication $(\mathrm{I})$ and hotels and restaurants $(\mathrm{H})$, the services industries all show positive average growth rates in both hours and labour composition across the entire period. An increase in the average growth rate for labour composition has been especially marked in financial intermediation $(\mathrm{J})$. However, its growth rate decreased for hours, indicating that employment in this industry is becoming dominated by relatively well remunerated workers. Although other services has the second highest average growth rate for labour composition in the later period, this is still down by a noticeable amount compared to the earlier 
period. Real estate, renting and business activities $(\mathrm{K})$ has seen labour composition growth decline by a percentage point, the largest decline by far for all industries.

These growth rates reflect the compositional movements of the employed workforce; the age, qualification level and predominant gender of workers in these industries may explain some of the changes, or it could be related to structural change in the industry in question. However, nothing can be said about the relative strengths of these effects because the EU KLEMS dataset only reports 'labour services' by industry.

\section{Conclusion}

This article presented new estimates of quality-adjusted labour inputs between the years 1993 and 2009. As the adjustment categories show a high level of consistency with the EU KLEMS 'labour services' measure, backcasting the QALI time series on an annual basis to 1970 was also possible.

Making explicit adjustment for the quality of the workforce has the effect of increasing estimated labour input to the production process. The magnitude of the quality-adjustment, or labour composition, at the whole economy level has been increasing over time. The observed impact tends to be greatest in service industries, with financial intermediation exhibiting the largest increase in labour composition, while growth in QALI itself was highest in real estate, renting and business activities. For the majority of industries, labour composition increased over the recession whilst growth in hours declined. These results suggest that the low-skilled suffered more than the high-skilled over the downturn as the employed workforce moved to higher-remunerated QALI categories, on average.

Within adjustment groups, the overall trend has been towards growth in hours worked by those with undergraduate and postgraduate qualifications at the expense of workers with little or no qualification, and those over 50 compared to the young. Growth in both QALI and labour composition has been far stronger for women than for men over the period studied. The recession had little impact on older workers whilst it impacted quite notably on younger workers. The labour market position of those with the highest level of qualifications improved over the downturn.

Analysing labour inputs over a longer period, using the growth profile of the 'labour services' series, highlights how the growth of labour composition and hours, and thus QALI, have changed over time. Financial intermediation and real estate, renting and business activities, in particular, have seen notable growth rate changes since the 1970s.

\section{Notes}

1. The EU KLEMS project, which ran from 2003 to 2008, created a database on measures of economic growth, productivity, employment creation, capital formation and technological change at the industry level for all European Union member states from 1970 onwards. Its equivalent of QALI is referred to as 'labour services'. Further details available at: http://www.euklems.net/ 
2. Employment is a head-count of all participants in the labour market. A jobs measure differs from head-count measures like employment as it takes account of workers with second jobs.

3. Productivity hours and productivity jobs are series used in the calculation of headline ONS labour productivity measures, available at www.statistics.gov.uk/STATBASE/Product.asp?vlnk=7476. They provide conceptually consistent measures of the volume of labour input for productivity purposes as they are produced using more reliable industry breakdowns, from both short-term and annual business surveys, which are constrained to LFS aggregates.

4. Productivity jobs and productivity hours were both extracted from the Q3 2010 Labour Productivity Statistical Bulletin for use in this article. However, there have been revisions to both series since that release, which are available in the Q4 2010 bulletin.

5. The calculation is performed by dividing gross annual pay by total hours for each QALI category, with both variables obtained from the LFS micro-data.

6. QALI is a Törnqvist weighted index of hours, where the weights are labour income shares. The difference between this index and an unadjusted index of hours from the LFS represents 'labour composition', expressed in index points. Where QALI is greater than hours, this implies that labour composition is moving towards QALI categories with higher wages, on average.

7. These refer to National Vocational Qualifications (NVQ), which are recorded in the LFS microdata. For ease of interpretation, descriptive categories are used, but these refer to NVQ levels.

8. See 'Older people in the labour market' for further details:

www.statistics.gov.uk/cci/nugget.asp?id=2648

9. See 'Graduates in the labour market' for further details:

www.statistics.gov.uk/CCl/nugget.asp?ID=1162

10. See the Labour Marked Statistical Bulletins for further details:

www.statistics.gov.uk/STATBASE/Product.asp?vlnk=1944

11. See O'Mahony and Timmer (2009) for further details on EU KLEMS and Dunn, Goodridge and Turvey (2010) for an evaluation of EU KLEMS.

12. This suggests an alternative methodology for backcasting may be possible that involves using EU KLEMS labour composition combined with an ONS-produced hours series.

\section{Contact}

elmr@ons.gov.uk 


\section{References}

Appleton (2011) 'Volume index of capital services: new annual and quarterly estimates for 1950 to 2009', Economic \& Labour Market Review forthcoming

Bell V, Burriel-Llombart P and Jones J (2005) 'A quality-adjusted labour input series for the United Kingdom (1975-2002)', Bank of England Working Paper No. 280

Dunn R, Goodridge P and Turvey A (2010) 'Evaluation of the EU KLEMS analytical database Labour Accounts and Intermediate Inputs'. Report compiled for Eurostat.

EU KLEMS (2007a) ‘EU KLEMS Growth and Productivity Accounts, Part 1: Methodology’

EU KLEMS (2007b) ‘EU KLEMS Growth and Productivity Accounts, Part 2: Sources by Country’

Goodridge P (2007) 'Methods Explained: Index Numbers', Economic and Labour Market Review $1(3)$, pp 54-57 and at www.statistics.gov.uk/cci/article.asp?ID=1743

Goodridge P (2009) 'Quality-adjusted labour input: estimates for 1997 to 2007', Economic and Labour Market Review 3(1), pp 62-66 and at www.statistics.gov.uk/cci/article.asp?ID=2102

O'Mahony M and Timmer M.P (2009) 'Output, input and productivity measures at the industry level: the EU KLEMS database', The Economic Journal 119 (June), pp 374-403.

Organisation for Economic Co-operation and Development (2001) 'Measuring Productivity OECD Manual'.

Turvey A (2009) 'Developing a unit labour costs indicator for the UK', Economic and Labour Market Review 3(6), pp 51-56 and at www.statistics.gov.uk/cci/article. asp?id=2218

Turvey A, Goodridge P and Franklin M (2010) 'Quality adjusted labour input: new estimates for 1993 to 2008', Economic \& Labour Market Review 4(10), pp 113-131 and at www.statistics.gov.uk/cci/article.asp?ID=2596 